\title{
Spatial and statistical analysis on the cause of flooding in Northwest Jakarta floodplain (Kapuk and Penjaringan Districts)
}

\author{
Imam Priambodo ${ }^{1}$ Mangapul P.Tambunan ${ }^{2}$, Eko Kusratmoko ${ }^{2}$ \\ ${ }^{1}$ Postgraduate student at Department of Geography, University of Indonesia, Depok, 16424, Indonesia \\ ${ }^{2}$ Lecturer at Department of Geography, University of Indonesia, Depok, 16424, Indonesia
}

\begin{abstract}
Jakarta, as the capital city of Indonesia, is one of the most flooded areas in Indonesia. The floods occurred annually and heavy floods usually occurred once in a few years. This paper address the geographic distribution of floods and statistical analysis of the floods causes by using rain intensity, tidal height, elevation, and floods occurrence as the parameters. This research was conducted in Angke (Kapuk) and Penjaringan Districts, located in Northern Jakarta where the floods usually occur. The result shows that rainfall intensity, remaining water inundation from the previous flood, and land runoff coefficient as the key factors of flooding in these areas.
\end{abstract}

\section{Introduction}

Flooding has been an annual natural disaster in Jakarta every year [1]. The increase of population, intensively building construction and climate change cause the flood factors become more complex, therefore, it requires more comprehensive analysis [2].

This research investigates the main cause of flooding in Kapuk District and Penjaringan District, which are the most flooded areas in Jakarta. The results are considered as the solution in mitigating of the flood disaster in Jakarta.

\section{Flooding in Muara Angke Basin}

The area of interest of this study is Angke District and Penjaringan district located in West Jakarta, as shown in Fig. 1. Angke District has $16 \mathrm{RWs}$ (community groups) with 700 hectares of land and Penjaringan District has 17 RWs with 500 hectares of land.

In this study, the available floods data from the Jakarta Disaster Mitigation Agency (BPBD Jakarta) from January 2013 to December 2016 was used as references. The floods are defined as an overflow of water that submerges dry land areas above $30 \mathrm{~cm}$.

\section{Types of flood}

Geomorphologically, Jakarta is a low-land area where thirteen (13) rivers flow within the region. The rivers are Cakung river, Jatikramat river, Buaran river, Sunter river, Cipinang river, Ciliwung river, Cideng river, Krukut river, Grogol river, Angke river, and Mookervert river, as shown in Fig. 2.

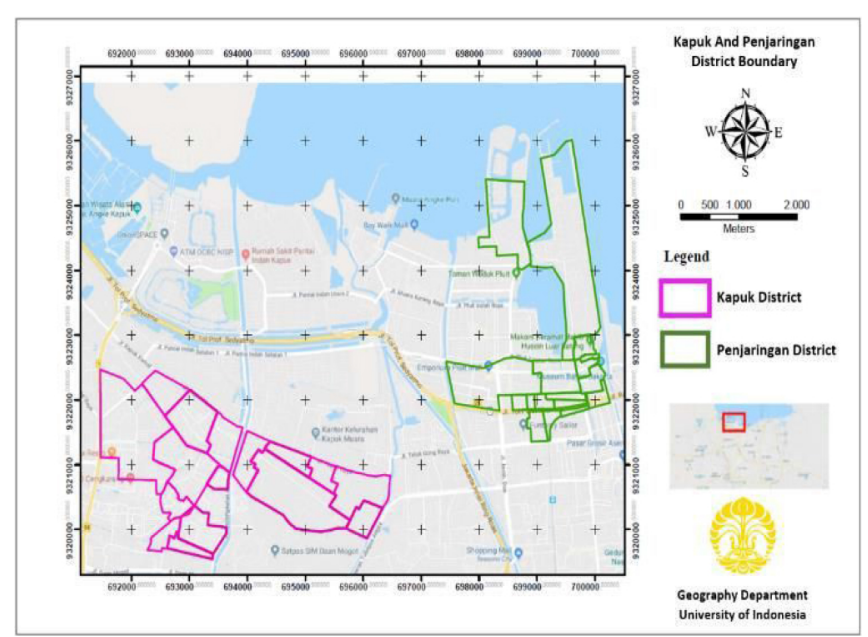

Fig. 1. Boundary map of study area. Red dots are the district's boundary, blue are rivers, and cyan is the coastal boundary

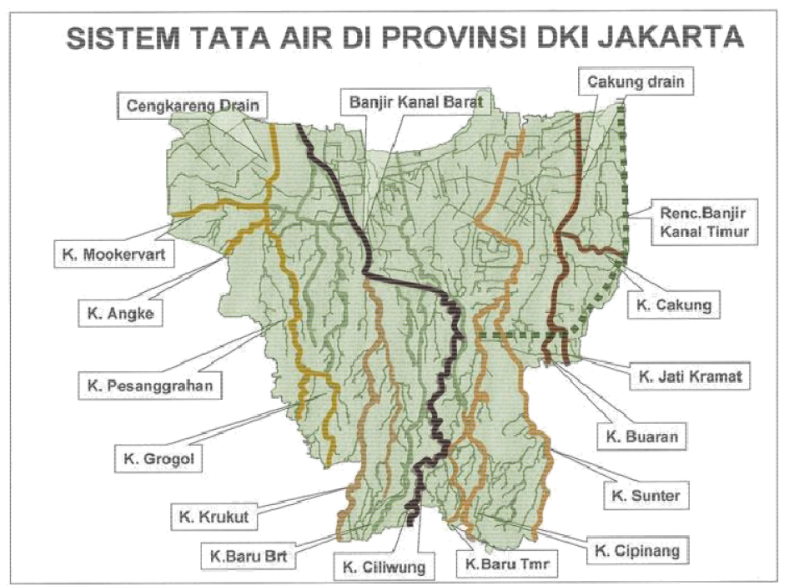

Fig.2. Rivers in Jakarta Region

\footnotetext{
${ }^{*}$ Corresponding author: imam.priambodo@gmail.com
} 
The average annual rainfall intensity in Jakarta is high, about 2000-3000 $\mathrm{mm}$ [3]. The area also directly affected by a tidal wave is about $40 \%(24,000$ hectares $)$ of total area (64,000 hectares). Both parameters increase the risk factor of flooding in Jakarta.

According to National Meteorology, Climatology, and Geophysics Bureau (BMKG) data based on 10-year analysis using 20 independent rain gauges [4], the heaviest rainfall occurs on January and February, which is about $365 \mathrm{~mm}-$ $329 \mathrm{~mm} /$ month and in some cases it is $>400 \mathrm{~mm}$ at Rorotan and Tanjung Priok sub-districts.

\subsection{Heavy rainfall floods}

When rain falls for a long time, the soil that serves as a water absorbent medium can become saturated. If the water is unable to infiltrate the already saturated soil, it causes the water to flow above the soil, increasing the runoff and consequently, the existing rivers are unable to accommodate excessive rainwater. This makes the water will overflow to the banks of their neighboring lands.

\subsection{Coastal floods}

Coastal flood is when the coast is flooded by the sea. It occurs when normally dry, the low-lying land is flooded by seawater.

Coastal floods have some characteristics:

1. Occurs when the tide is high

2. Watercolor is not too cloudy

3. Not always occurs in the rainy season (sometimes it occurs during the dry season)

4. Usually occurs in areas that have a lower elevation than the ocean

\subsection{Surface / Pluvial floods}

Pluvial floods is a condition in where there is a high flood in an area with a low level of soil absorption, causing a slow disposal of water and absorption to the soil that results in inundation of the land area more than one (1) day although on that day there is no rain or rain occurs with low intensity. There are several factors that can cause a Pluvial flood, namely:

\section{1) Low soil elevation}

A condition where the elevation of an area is lower or equal to seawater, resulting in a slow flow of drainage into the sea.

\section{2) Conversion of land}

Conversion of land is the conditions where the function of the land change that causes the surface layer of soil that previously can absorb water easily become hard to absorb water properly.

\section{3) Blockage of water flow}

The condition where there is a blockage of the flow of drainage into the sea that caused by various things such as piles of garbage, siltation of the river due to mud, or the overbuilt river banks.

\section{Analysis of floods causes}

To analyze the cause of floods in Jakarta, Table 1 shows the list of the variables that will be used in the statistical analysis using multiple linear regression method.

Table 1. Cause of floods variables

\begin{tabular}{|c|c|c|c|}
\hline No & Variables & Definition & Unit \\
\hline 1 & Tide & $\begin{array}{l}\text { The height of the } \\
\text { tides (tides) of } \\
\text { seawater during } \\
\text { the observation } \\
\text { hour recorded at } \\
\text { the tidal station }\end{array}$ & $\begin{array}{l}\text { Centimeter } \\
(\mathrm{cm})\end{array}$ \\
\hline 2 & Rain intensity & $\begin{array}{l}\text { The amount of } \\
\text { rainfall in one day } \\
\text { per square meter } \\
\left(\mathrm{m}^{2}\right)\end{array}$ & $\begin{array}{l}\text { Millimeter } \\
(\mathrm{mm}) / \text { day }\end{array}$ \\
\hline 3 & Soil Type & $\begin{array}{l}\text { Type of soil in the } \\
\text { study area }\end{array}$ & - \\
\hline 4 & $\begin{array}{c}\text { Land Use } \\
\text { Classification }\end{array}$ & $\begin{array}{l}\text { Types of land use } \\
\text { based on the land } \\
\text { use } \\
\text { classification }\end{array}$ & - \\
\hline 5 & Elevation & \begin{tabular}{|lr} 
Ground & level \\
altitude & based \\
Mean Sea & Level \\
(MSL) &
\end{tabular} & Meter $(\mathrm{m})$ \\
\hline 6 & $\begin{array}{l}\text { Floods } \\
\text { Frequency }\end{array}$ & $\begin{array}{l}\text { Number of flood } \\
\text { events per Rukun } \\
\text { Warga (RW) for } \\
\text { four (4) years } \\
\text { from } 2013-2016\end{array}$ & - \\
\hline
\end{tabular}

Water Runoff coefficients are used to calculate the runoff volume that may occur in the event of rain, which can be calculated by using the Rational method.

$$
\mathrm{Q}=0.278 \text {.C.I.A }
$$

Where:

$$
\begin{aligned}
& \mathrm{W}=\text { Runoff volume }\left(\mathrm{m}^{3} / \mathrm{s}\right) \\
& \mathrm{C}=\text { Runoff coefficient } \\
& \mathrm{I}=\text { Rain intensity }(\mathrm{mm} / \mathrm{h}) \\
& \mathrm{A}=\text { Surface area (hectares) }
\end{aligned}
$$

\subsection{Tidal wave calculation}

Typically, the method used to calculate tidal wave is the Admiralty method to obtain harmonic constants on through tidal equations.

$$
A_{(t)}=S_{n}+A_{n_{n=1}^{n=k}}^{n=} \cdot \cos \left(W-G_{n}\right)
$$

Where,

$\mathrm{A}(\mathrm{t}) \quad=$ Amplitude

So $\quad=$ Mean Sea Level(MSL)

An $=$ Amplitude of tidal harmonic components.

$\mathrm{Gn} \quad=$ Phase of tidal components

$\mathrm{n} \quad=$ constants obtained from astronomical calculations

$\mathrm{t}=$ time 


\subsection{Rain intensity}

Rain intensity is the amount of rain expressed in rainfall or rainfall volume per unit time. Rain intensity for short durations of time can be estimated using the Mononobe formula.

$$
I=\frac{R_{24}}{24}\left(\frac{24}{t}\right)^{2 / 3}
$$

Where,

$$
\begin{aligned}
\mathrm{I} & =\text { Rain intensity }(\mathrm{mm} / \mathrm{h}) \\
\mathrm{T} & =\text { Rain fall period }(\mathrm{h}) \\
\mathrm{R} 24 & =\text { Maximum rainfall in } 24 \text { hours }(\mathrm{mm})
\end{aligned}
$$

\subsection{Linear regression}

Multiple linear regression analysis is a linear relationship between two or more independent variables $(\mathrm{X} 1, \mathrm{X} 2, \ldots . \mathrm{Xn})$ with the dependent variable of (Y). This analysis is commonly used to determine the relationship between independent variables with dependent variables whether each independent variable is positive or negative and to predict the value of the dependent variable if the value of the independent variable increases or decreases. The data used are usually scaled in intervals or ratios.

$$
Y^{\prime}=a+b 1 X 1+b 2 X 2+\ldots . .+b n X n
$$

Where:

Y $\quad=$ Dependent variable (predicted

value) $\mathrm{X} 1, \mathrm{X} 2 \quad=$ Independent variables

$$
\begin{array}{ll}
\mathrm{a} & =\text { Constants } \\
\mathrm{b} & =\text { Regression's coefficient }
\end{array}
$$

\section{Flood occurrences and tidal height in Kapuk and Penjaringan District at flood's time}

\begin{tabular}{|c|c|c|c|c|}
\hline 13 & 15-Jan-13 & Penjaringan & 17 & 100 \\
\hline 14 & 17-Jan-13 & Penjaringan & 17 & 100 \\
\hline 15 & 18-Jan-13 & Penjaringan & 17 & 100 \\
\hline 16 & 19-Jan-13 & Penjaringan & 17 & 100 \\
\hline 17 & 20-Jan-13 & Penjaringan & 17 & 100 \\
\hline 18 & 21-Jan-13 & Penjaringan & 17 & 100 \\
\hline 19 & 22-Jan-13 & Penjaringan & 17 & 100 \\
\hline 20 & 23-Jan-13 & Penjaringan & 17 & 100 \\
\hline 21 & 24-Jan-13 & Penjaringan & 17 & 100 \\
\hline 22 & 25-Jan-13 & Penjaringan & 17 & 100 \\
\hline 23 & 26-Jan-13 & Penjaringan & 17 & 100 \\
\hline 24 & 27-Jan-13 & Penjaringan & 17 & 100 \\
\hline 25 & $28-\operatorname{Jan}-13$ & Penjaringan & 17 & 100 \\
\hline 26 & 29-Jan-13 & Penjaringan & 17 & 100 \\
\hline 27 & 14-Jan-14 & Kapuk & 16 & 70 \\
\hline 28 & 15-Jan-14 & Kapuk & 16 & 70 \\
\hline 29 & 16-Jan-14 & Kapuk & 16 & 70 \\
\hline 30 & 17-Jan-14 & Kapuk & 16 & 70 \\
\hline 31 & 18-Jan-14 & Kapuk & 16 & 70 \\
\hline 32 & 19-Jan-14 & Kapuk & 16 & 70 \\
\hline 33 & 20-Jan-14 & Kapuk & 16 & 70 \\
\hline 34 & 21-Jan-14 & Kapuk & 16 & 70 \\
\hline 35 & 22-Jan-14 & Kapuk & 16 & 70 \\
\hline 36 & 23-Jan-14 & Kapuk & 16 & 70 \\
\hline 37 & 24-Jan-14 & Kapuk & 16 & 70 \\
\hline 38 & 25-Jan-14 & Kapuk & 16 & 70 \\
\hline 39 & 26-Jan-14 & Kapuk & 16 & 70 \\
\hline 40 & 27-Jan-14 & Kapuk & 16 & 70 \\
\hline 41 & 18-Jan-14 & Penjaringan & 4 & 50 \\
\hline 42 & 19-Jan-14 & Penjaringan & 4 & 50 \\
\hline 43 & 20-Jan-14 & Penjaringan & 4 & 50 \\
\hline 44 & 21-Jan-14 & Penjaringan & 4 & 50 \\
\hline 45 & 22-Jan-14 & Penjaringan & 4 & 50 \\
\hline 46 & 23-Jan-14 & Penjaringan & 4 & 50 \\
\hline 47 & 24-Jan-14 & Penjaringan & 4 & 50 \\
\hline 48 & 29-Jan-14 & Penjaringan & 4 & 50 \\
\hline 49 & 30-Jan-14 & Penjaringan & 4 & 50 \\
\hline 50 & 31-Jan-14 & Penjaringan & 4 & 50 \\
\hline 51 & 22-Feb-14 & Kapuk & 7 & 80 \\
\hline 52 & 23-Feb-14 & Kapuk & 7 & 80 \\
\hline 53 & 24-Feb-14 & Kapuk & 7 & 80 \\
\hline 54 & $25-F e b-14$ & Kapuk & 7 & 80 \\
\hline 55 & 26-Feb-14 & Kapuk & 7 & 80 \\
\hline 56 & 27-Feb-14 & Kapuk & 7 & 80 \\
\hline 57 & 28 -Feb-14 & Kapuk & 7 & 80 \\
\hline 58 & 23-Jan-15 & Kapuk & 4 & 40 \\
\hline
\end{tabular}

Table 2 shows the occurrences of floods in Kapuk and Penjaringan District. The maps of floods geographical distribution in the area between 2013 and 2016 are shown in Figs. 3-6.

Table 2. Date of flood occurrences

\begin{tabular}{|c|c|c|c|c|}
\hline No & Date & Location & $\begin{array}{c}\text { Affected } \\
\mathbf{R W}\end{array}$ & $\begin{array}{c}\text { Depth } \\
(\mathbf{c m})\end{array}$ \\
\hline 1 & $14-J a n-13$ & Kapuk & 16 & 160 \\
\hline 2 & $16-J a n-13$ & Kapuk & 16 & 160 \\
\hline 3 & $17-J a n-13$ & Kapuk & 16 & 160 \\
\hline 4 & $18-J a n-13$ & Kapuk & 16 & 160 \\
\hline 5 & 19-Jan-13 & Kapuk & 16 & 160 \\
\hline 6 & 20-Jan-13 & Kapuk & 16 & 160 \\
\hline 7 & 21-Jan-13 & Kapuk & 16 & 160 \\
\hline 8 & 22-Jan-13 & Kapuk & 16 & 160 \\
\hline 9 & 23-Jan-13 & Kapuk & 16 & 160 \\
\hline 10 & 24-Jan-13 & Kapuk & 16 & 160 \\
\hline 11 & 25-Jan-13 & Kapuk & 16 & 160 \\
\hline 12 & 14-Jan-13 & Penjaringan & 17 & 100 \\
\hline
\end{tabular}




\begin{tabular}{|c|c|c|c|c|}
\hline 59 & 24-Jan-15 & Kapuk & 4 & 40 \\
\hline 60 & $02-F e b-15$ & Kapuk & 14 & 100 \\
\hline 61 & 09-Feb-15 & Kapuk & 14 & 100 \\
\hline 62 & 10 -Feb-15 & Kapuk & 14 & 100 \\
\hline 63 & 11-Feb-15 & Kapuk & 14 & 100 \\
\hline 64 & 12 -Feb-15 & Kapuk & 14 & 100 \\
\hline 65 & 13 -Feb-15 & Kapuk & 14 & 100 \\
\hline 66 & 14-Feb-15 & Kapuk & 14 & 100 \\
\hline 67 & 09-Feb-15 & Penjaringan & 6 & 60 \\
\hline 68 & 10 -Feb-15 & Penjaringan & 6 & 60 \\
\hline 69 & $11-F e b-15$ & Penjaringan & 6 & 60 \\
\hline 70 & 12 -Feb-15 & Penjaringan & 6 & 60 \\
\hline 71 & 13 -Feb-15 & Penjaringan & 6 & 60 \\
\hline 72 & 26 -Feb-16 & Kapuk & 14 & 30 \\
\hline 73 & $27-F e b-16$ & Kapuk & 14 & 30 \\
\hline 74 & $29-F e b-16$ & $\overline{\text { Kapuk }}$ & 14 & 30 \\
\hline 75 & 01-Mar-16 & Kapuk & 3 & 15 \\
\hline 76 & 05 -Jun-16 & Penjaringan & 1 & 30 \\
\hline 77 & 07-Jun-16 & Penjaringan & 1 & 30 \\
\hline
\end{tabular}

The table above contains the date of floods, the area affected by the floods, and flood depth as reported by local officials

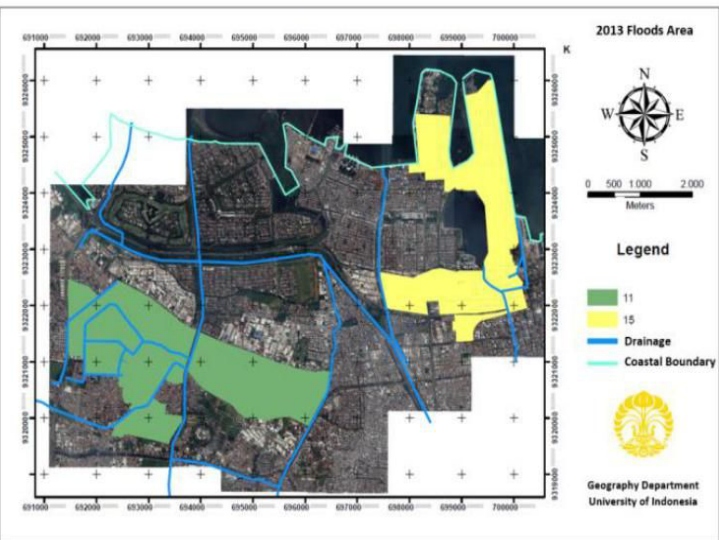

Fig. 3. Flood occurrences in 2013

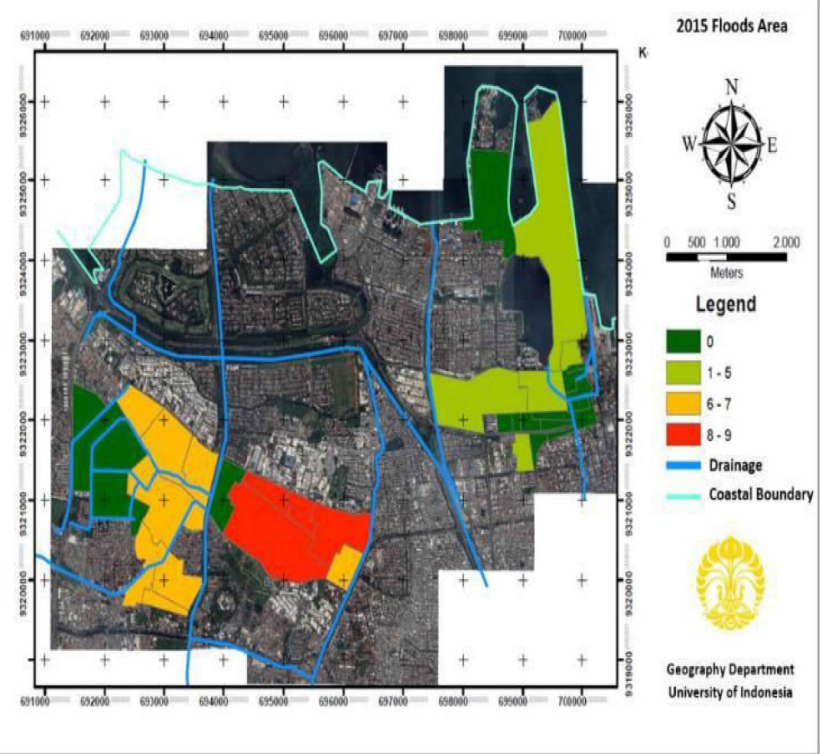

Fig. 5. Flood occurrences in 2015

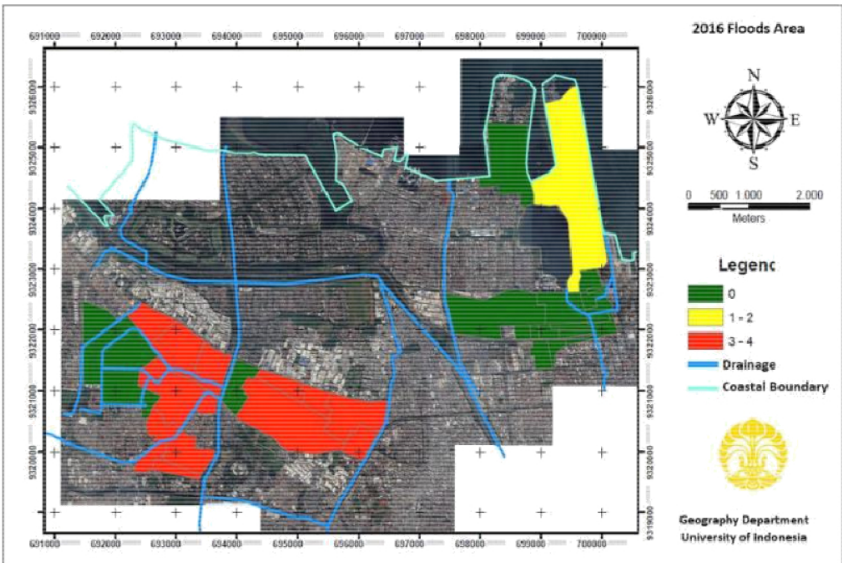

Fig. 6. Flood occurrences in 2016

For better flood analysis, we also include tides as one of the floods cause factor. Fig.7 shows the maximum daily tide height from the nearest tide station during the floods.

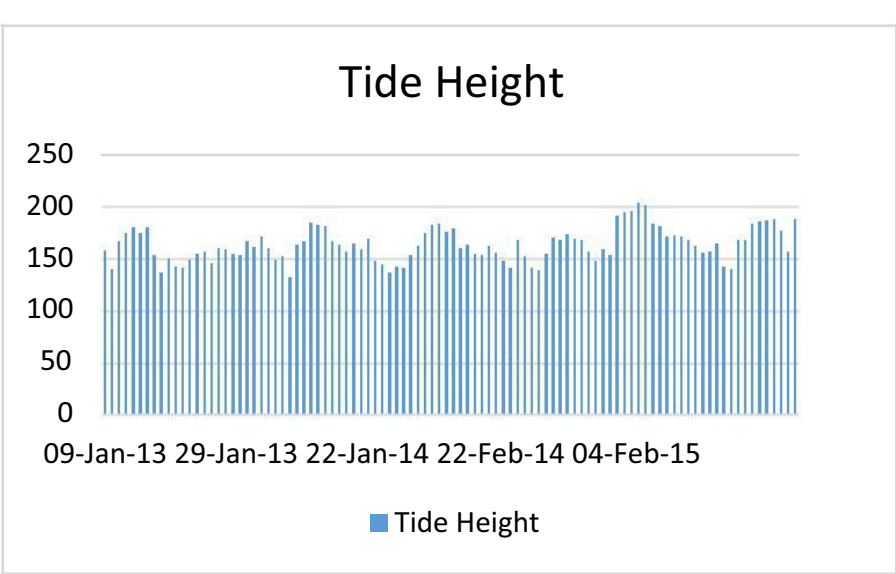

Fig.4. Flood occurrences in 2014

Fig.7. Maximum tide height 
Table 3. Highest tidal wave at floods time

\begin{tabular}{|c|c|c|}
\hline No & Date & $\begin{array}{l}\text { Max Height } \\
\text { (cm) }\end{array}$ \\
\hline 1 & 09-Jan-13 & 158 \\
\hline 2 & 10-Jan-13 & 140 \\
\hline 3 & 11-Jan-13 & 167 \\
\hline 4 & 12-Jan-13 & 175 \\
\hline 5 & 13-Jan-13 & 180 \\
\hline 6 & 14-Jan-13 & 175 \\
\hline 7 & 16-Jan-13 & 154 \\
\hline 8 & 17-Jan-13 & 137 \\
\hline 9 & 18-Jan-13 & 150 \\
\hline 10 & 19-Jan-13 & 143 \\
\hline 11 & 20-Jan-13 & 141 \\
\hline 12 & 21-Jan-13 & 149 \\
\hline 13 & 22-Jan-13 & 155 \\
\hline 14 & 23-Jan-13 & 157 \\
\hline 15 & 24-Jan-13 & 146 \\
\hline 16 & 25-Jan-13 & 160 \\
\hline 17 & 26-Jan-13 & 159 \\
\hline 18 & 27-Jan-13 & 155 \\
\hline 19 & 28-Jan-13 & 154 \\
\hline 20 & 29-Jan-13 & 167 \\
\hline 21 & 30-Jan-13 & 162 \\
\hline 22 & 09-Jan-13 & 158 \\
\hline 23 & 10-Jan-13 & 140 \\
\hline 24 & 11-Jan-13 & 167 \\
\hline 25 & 12-Jan-13 & 175 \\
\hline 26 & 13-Jan-13 & 180 \\
\hline 27 & 14-Jan-13 & 175 \\
\hline 28 & 15-Jan-13 & 180 \\
\hline 29 & 17-Jan-13 & 138 \\
\hline 30 & 18-Jan-13 & 150 \\
\hline 31 & 19-Jan-13 & 143 \\
\hline 32 & 20-Jan-13 & 141 \\
\hline 33 & 21-Jan-13 & 149 \\
\hline 34 & 22-Jan-13 & 155 \\
\hline 35 & 23-Jan-13 & 157 \\
\hline 36 & 24-Jan-13 & 146 \\
\hline 37 & 25-Jan-13 & 160 \\
\hline 38 & 26-Jan-13 & 154 \\
\hline 39 & 27-Jan-13 & 155 \\
\hline 40 & 28-Jan-13 & 154 \\
\hline 41 & 29-Jan-13 & 167 \\
\hline
\end{tabular}

\begin{tabular}{|c|c|c|}
\hline 42 & $11-F e b-13$ & 171 \\
\hline 43 & 12 -Feb-13 & 160 \\
\hline 44 & 13 -Feb-13 & 149 \\
\hline 45 & $14-F e b-13$ & 153 \\
\hline 46 & $15-F e b-13$ & 133 \\
\hline 47 & 09-Jan-14 & 164 \\
\hline 48 & 10-Jan-14 & 167 \\
\hline 49 & 11-Jan-14 & 185 \\
\hline 50 & 12-Jan-14 & 183 \\
\hline 51 & 13-Jan-14 & 181 \\
\hline 52 & 14-Jan-14 & 167 \\
\hline 53 & 15-Jan-14 & 164 \\
\hline 54 & 16-Jan-14 & 157 \\
\hline 55 & 17-Jan-14 & 165 \\
\hline 56 & 18-Jan-14 & 159 \\
\hline 57 & 19-Jan-14 & 169 \\
\hline 58 & 20-Jan-14 & 148 \\
\hline 59 & 21-Jan-14 & 144 \\
\hline 60 & 22-Jan-14 & 137 \\
\hline 61 & 23-Jan-14 & 142 \\
\hline 62 & 24-Jan-14 & 141 \\
\hline 63 & 25-Jan-14 & 154 \\
\hline 64 & 26-Jan-14 & 163 \\
\hline 65 & 27-Jan-14 & 175 \\
\hline 66 & 28-Jan-14 & 183 \\
\hline 67 & 29-Jan-14 & 184 \\
\hline 68 & 30-Jan-14 & 176 \\
\hline 69 & 31-Jan-14 & 179 \\
\hline 70 & 13-Jan-14 & 181 \\
\hline 71 & 14-Jan-14 & 167 \\
\hline 72 & 15-Jan-14 & 164 \\
\hline 73 & 16-Jan-14 & 157 \\
\hline 74 & 17-Jan-14 & 165 \\
\hline 75 & 18-Jan-14 & 159 \\
\hline 76 & 19-Jan-14 & 169 \\
\hline 77 & 20-Jan-14 & 148 \\
\hline 78 & 21-Jan-14 & 144 \\
\hline 79 & 22-Jan-14 & 137 \\
\hline 80 & 23-Jan-14 & 142 \\
\hline 81 & 24-Jan-14 & 141 \\
\hline 82 & 29-Jan-14 & 184 \\
\hline 83 & 30-Jan-14 & 176 \\
\hline 84 & 31-Jan-14 & 179 \\
\hline 85 & 01-Feb-14 & 160 \\
\hline 86 & 02-Feb-14 & 164 \\
\hline 87 & 03-Feb-14 & 155 \\
\hline
\end{tabular}




\begin{tabular}{|c|c|c|c|c|c|}
\hline 88 & 04-Feb-14 & 154 & 134 & 12 -Feb-15 & 140 \\
\hline 89 & $05-$ Feb-14 & 163 & 135 & $13-F e b-15$ & 168 \\
\hline 90 & $17-F e b-14$ & 156 & 136 & $14-F e b-15$ & 178 \\
\hline 91 & 18 -Feb-14 & 148 & 137 & 15 -Feb-15 & 184 \\
\hline 92 & 19-Feb-14 & 141 & 138 & $16-F e b-15$ & 186 \\
\hline 93 & 20-Feb-14 & 168 & 139 & $17-$ Feb-15 & 187 \\
\hline 94 & 21-Feb-14 & 153 & 140 & 18 -Feb-15 & 188 \\
\hline 95 & 22-Feb-14 & 141 & 141 & $13-F e b-16$ & 179 \\
\hline 96 & $23-F e b-14$ & 139 & 142 & $14-F e b-16$ & 197 \\
\hline 97 & 24-Feb-14 & 155 & 143 & 15 -Feb-16 & 203 \\
\hline 98 & 25 -Feb-14 & 170 & 144 & $16-$ Feb-16 & 209 \\
\hline 99 & $26-$ Feb-14 & 168 & 145 & $17-F e b-16$ & 196 \\
\hline
\end{tabular}

\section{Statistical analysis}

\subsection{Statistical analysis of relationship between rain intensity, tides, elevation and floods occurrence}

By using Linear Regression method using data from January 2013 to December 2016 as a dependent variable and daily rainfall data and tidal data (tide) of seawater as an independent variable, the obtained result is shown in Table. 4.

Table 4. Model summary of linear regression analysis

\begin{tabular}{|l|c|c|c|r|}
\hline Model & $\mathrm{R}$ & $\mathrm{R}$ Square & $\begin{array}{c}\text { Adjusted R } \\
\text { Square }\end{array}$ & $\begin{array}{c}\text { Std. Error of } \\
\text { the Estimate }\end{array}$ \\
\hline 1 & $.769^{\mathrm{a}}$ & .592 & .577 & .326 \\
\hline
\end{tabular}
a. predictors : (constant), Runoff, Rainfall, Tide height,
previous flood,Lidar elevation

The Summary Model explains how much independent factors can explain the occurrence of bound variables / Rsquared and adjusted R-square values are indicators of how much free variables are able to explain the changes that occur in the dependent variable. From the summary model, the value of Adjusted R Square value of .592 indicates that the factors/variables that formed can explain the flood incidence as much as $59.2 \%$, with other factors that have the chance of causing flood event of $32.6 \%$.

\subsection{F-Significance test}

F-significance test is performed to test the model simultaneously or in a bundle. The test is called the simultaneous test (F-Test) aims to see whether together independent variables affect the dependent variable or not. The test is statistically written as follows :

Hypothesis:

$\mathrm{H} 0: \beta 0=\beta 1=\beta 2=\beta 3=\beta 4=0$

$\mathrm{H} 1$ : there is at least one non-zero $\beta \mathrm{i}$

Significance level : $\mathrm{a}=0.001 / 99.9 \%$

Critical value: Reject H0 if significance value more than ' $a$ ' 
If significance value $=0.000$, reject $\mathrm{H} 0$. Or we can compare the $F$ value in the result table with the $F$ value in the standard $F$ table. To determine whether the inserted free variable meets the tolerance requirement or not, the calculated $\mathrm{F}$ value must be greater than the $\mathrm{F}$ table value ( $\mathrm{F}$ arithmetic $>\mathrm{F}$ table). $\mathrm{F}$ table value can be searched by first determining the degree of freedom (degree of freedom/df) from data, which is:

$\begin{array}{ll}\mathrm{df} 1 & =\mathrm{k}-1 \\ \mathrm{df} 2 & =\mathrm{n}-\mathrm{k}\end{array}$

Where,

$\mathrm{k}=$ number of independent variables + independent variable

df $1=$ degree of freedom $1(\mathrm{~N} 1)$

df2 = degree of freedom $2(\mathrm{~N} 2)$

Then,

$$
\begin{aligned}
\text { df1 } & =5-1 \\
& =4 \\
\text { df } 2 & =145-4 \\
& =141
\end{aligned}
$$

\begin{tabular}{|c|c|c|c|c|c|c|}
\hline \multicolumn{7}{|c|}{ ANOVA $^{\mathrm{b}}$} \\
\hline & & $\begin{array}{c}\text { Sum of } \\
\text { Squares }\end{array}$ & $\mathrm{df}$ & Mean Square & $\mathrm{F}$ & Sig. \\
\hline \multirow[t]{3}{*}{1} & Regression & 21.446 & 5 & 4.289 & 40.317 & $.000^{\mathrm{a}}$ \\
\hline & Residual & 14.788 & 139 & .106 & & \\
\hline & Total & 36.234 & 144 & & & \\
\hline
\end{tabular}

Table 5. ANOVA table

From $\mathrm{F}$ test result with a probability of $99.9 \%(0.001)$, it shows that the model formed has a high significance value (Sig. $<0.000)$ with the value of F count (40.317) larger than $\mathrm{F}$ table (3.46) which means these variables influence the chance level of the flood disaster convincingly.

\subsection{Regression's Coefficient}

Table 6 shows the results of the analysis of each independent variable relative to the independent variables (probability of flood occurrence) which are obtained from SPSS analysis.

\begin{tabular}{|c|c|c|c|c|c|}
\hline \multicolumn{6}{|c|}{ coefficient (a) } \\
\hline \multirow[b]{2}{*}{ Model } & \multicolumn{2}{|c|}{ Unstandardized coefficients } & \multirow{2}{*}{\begin{tabular}{|l|}
$\begin{array}{l}\text { Standardize } \\
\text { Coefficients }\end{array}$ \\
Beta \\
\end{tabular}} & \multirow[b]{2}{*}{1} & \multirow[b]{2}{*}{ Sig. } \\
\hline & $B$ & std. Error & & & \\
\hline 1 (constant) & $-4,240$ & 0,858 & & $-4,941$ & 0,000 \\
\hline Rainfall & $-0,002$ & 0,001 & 0,219 & 3,773 & 0,000 \\
\hline Tide height & $-0,004$ & 0,002 & $-0,135$ & $-2,169$ & 0,032 \\
\hline Previous flood & 0,653 & 0,073 & 0,568 & 8,965 & 0,000 \\
\hline Lidar elevation & $-0,549$ & 0,089 & $-0,848$ & $-6,148$ & 0,000 \\
\hline Runoff & 12,569 & 1,938 & 0,886 & 6,487 & 0,000 \\
\hline
\end{tabular}
Column 'B' is the multiplier factor of each independent variable (coefficient).

Table 6. Coefficient Table

b. dependent variable : flood event

From the above results, then we can see the magnitude of the coefficient of each independent variable to the dependent variable, along with the level of significance. Based on the above results, Rainfall variables, Previous Flood Events, Elevation, and Water Runoff Coefficients have a very high significance which greater than $99.9 \% \quad(<0.000)$ and elevation has a low level of significance of $96.8 \%$ (0.032).

The value of regression equation calculation result is :

$\mathrm{Y}=0.936+0.003 \mathrm{X} 1-0.004 \mathrm{X} 2+0.676 \mathrm{X} 3-0,18 \mathrm{X} 4$

Where,

$\mathrm{Y}=$ Probability of flood occurence

$\mathrm{X} 1=$ Rain intensity $(\mathrm{mm})$

$\mathrm{X} 2$ = Tides maximum height

$\mathrm{X} 3$ = Floods from a day before $(0=$ No, $1=$ Yes $)$

$\mathrm{X} 4=$ Elevation

\subsection{Normal distribution table plot}

Fig. 8 shows a plot of normal distribution for the flood event, equations with free variables in the form of daily rainfall, highest tide, elevation, and previous flood events. From the figure, it can be seen that distribution pattern most likely increase when a certain value/quantity is input into the regression equation.

\section{dependent variable : flood event}

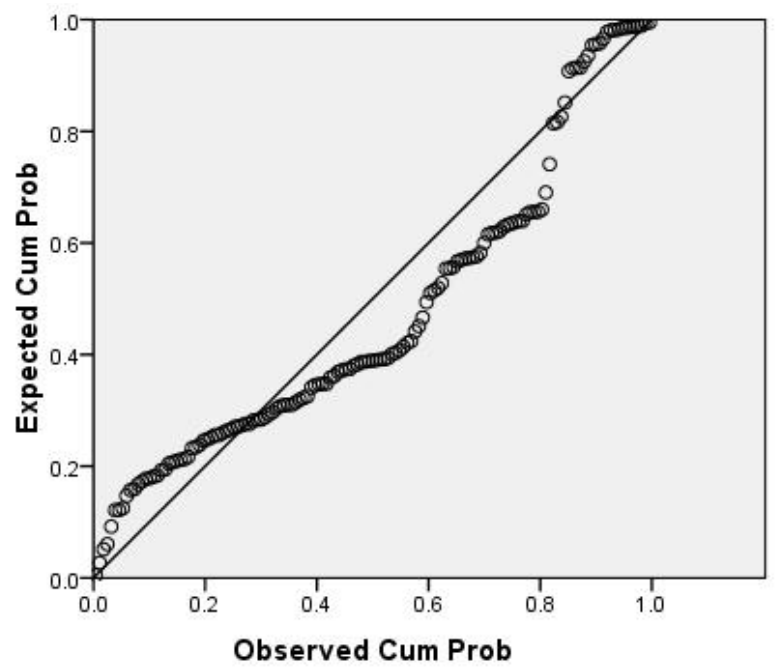

Fig. 8. Normal distribution plot of flood's probability

\section{Conclusions}

Based on the statistical analysis, it can be concluded that the highest contributor of flooding in Angke and Penjaringan areas are rainfall intensity, lands elevation, runoff coefficient, and the excess of the flood (Pluvial or surface flood) from the previous day which hasn't recede.

This excessive flood is directly correlated with water runoff coefficient, where the higher coefficient indicates that a large amount of water can't be absorbed into the soil because the surface is covered by hard materials such as asphalt and buildings.

The slow drainage of floods water also caused by blockage of water drainage which can be caused by several factors such as a heap of wastes at the housing water drainage, a deposit of soils at the riverbanks, insufficient water in catchment area caused by the land conversion, and the low elevation of Northern part of Jakarta itself. 
We would like to thank Regional Disaster Management Agency (BPBD) of Jakarta for record of flood occurrences in Angke and Penjaringan regions, Badan Meteorologi, Klimatologi, dan Geofisika (BMKG) of Republic of Indonesia for record of rain intensity, and Badan Informasi Geospasial (BIG) of Republic of Indonesia for record of tidal wave data.

\section{References}

1. Hartanto, Sudarsono, "Jakarta Flood Disaster Management, Tokyo, (2014)

2. Y. Budiyono, Aerts.J.C, Tollenaar, Ward.P.J,. "River Flood Risk in Jakarta Under Scenarios of Future Change, Journal of Natural Hazards and Earth System Sciences, (2016)

3. Meteorology, Climatology and Geophysics Agency (BMKG), " Analysis of Jakarta Province Flood Events on February 9, 2015, Meteorology, Climatology and Geophysics Agency (BMKG), Tangerang, (2015) (In Indonesia)

4. Brinkman, JanJaap, Hartman, Marco, Jakarta Flood Hazard Mapping

Framework, The IEEE website. [Online]. Available: http://www.ieee.org/, (2002)

5. European Commission, Risk Assessment and Mapping Guidelines for Disaster Management, European Union, Brussels, (2010)

6. G. Huffman., Bolvin. D,. TRMM and Other Data Precipitation Data Set Documentation, NASA Goddard Space Flight Center "PDCA12-

70 data sheet', (2017)

7. L.M. Hutasoit, "Land Crash and Its Relationship with Jakarta Reclamation", Indonesian Geological Association, Jakarta, (2016) (In Indonesia)

8. Y. Malole. "Critical Causes Analysis of Jakarta Floods"

9. G.C. Nanson., Croke, "A genetic classification of floodplains, University of Wollongong, Australia, (1992)
10. McCuen, Richard H,." Hydrology Analysis and Design. Prentice-Hall. 2ed, (1998)

11. I. Ratnasari., Putra. A.B, "Analysis of Atmospheric Conditions in Flood Events in the South Jakarta Region," Meteorology, Climatology and Geophysics College, Jakarta, (2016) (In Indonesia)

12. P.N. Sutopo., "Analysis of Rainfall Causes of Large Floods in Jakarta in Early February 2007", Agency for the Assessment and Application of Technology (BPPT), (2008) (In Indonesia)

13. United Nation International Strategy for Disaster Reduction (UNISDR). "UNISDR Terminology on Disaster Risk Reduction, United Nation", Geneva, (2009)

14. E. Wohl., "Inland Flood Hazards", Cambridge University Press, (2000)

15. E. Wohl., "Rivers in The Landscape, Colorado State University, USA, (2014)

16. N. Bagus, "Data on Floods in Indonesian Regions in Early 2017", (In Indonesia) https://news.detik.com/berita/3429421/data-banjir-disejumlah-wilayah-indonesia-di-awal-2017, Jakarta, (2017) 